\title{
PENDIDIKAN ISLAM BERBASIS INKLUSIFISME DALAM KEHIDUPAN MULTIKULTUR
}

\author{
Nasri Kurnialoh dan Sri Suharti \\ STAI H. Agus Salim Bekasi Indonesia \\ nasri_kurnialloh12@yahoo.co.id
}

\begin{abstract}
INCLUSIVE-BASED OF ISLAMIC EDUCATION IN MULTICULTURAL LIFE. Islamic education is working to create a balance and equality relations between the various groups that are integral and interdependent. Therefore, the life of this world requires an integral relations, mutual mutual assistance and cooperation in the midst of a people of Indonesia are very diverse, both in terms of ethnicity, religion or culture often gets serious examination with a lot of conflict in Indonesia. Much of the conflict was followed by acts of violence that occur because of a lack of public awareness of the cultural and religious teachings, especially the teachings of Islam for its adherents. Looking at the various conflicts and causes in Indonesia Muslims as the greatest people in Indonesia need to have a basic understanding and extensive knowledge of life together in various differences. In this case there is a paradigm known as Islamic thought inclusive paradigm that is identical with an attitude of openness, tolerance and the spirit of good cooperation between the followers of Islam and the other religions.
\end{abstract}

Keywords: Islamic Education, Inclusive Thought, Social Multicultural. 


\section{Abstrak}

Pendidikan Islam diterapkan untuk menciptakan bubungan yang seimbang dan setara antara berbagai kelompok yang merupakan bagian integral dan saling membutubkan. Oleh karena itu, kebidupan dunia ini membutubkan bubungan yang tidak terpisabkan, saling membantu dan saling kerjasama di tengah-tengah masyarakat Indonesia yang sangat beragam, baik dari segi etnis, agama atau budaya sering mendapat perbatian serius dengan banyak konflik di Indonesia. Banyak konflik diikuti oleh tindak kekerasan yang terjadi karena kurangnya kesadaran masyarakat tentang ajaran budaya dan agama, terutama ajaran Islam untuk pemeluknya. Melihat berbagai konflik dan penyebab di Indonesia Muslim sebagai masyarakat terbesar di Indonesia perlu memiliki pemahaman dasar dan pengetabuan yang luas dari kehidupan bersama dalam berbagai perbedaan. Dalam hal ini ada sebuah paradigma yang dikenal sebagai paradigma inklusif pemikiran Islam yang identik. dengan sikap keterbukaan, toleransi dan semangat kerjasama yang baik antara para pengikut Islam dan agama-agama lain.

Kata kunci: pendidikan Islam, pemikiran inklusif, multikultur sosial

\section{A. Pendahuluan}

Indonesia merupakan negara yang berpenduduk majemuk, betapa tidak, negara ini dihuni oleh suku bangsa yang plural dengan aneka ragam agama atau kepercayaan, suku (yang tersebar di lebih dari 17 ribu pulau) bahasa daerah yang mencapai lebih dari 500 bahasa dan budaya. Setiap individu yang hidup di negara ini pasti berhadapan dengan keanekaragaman, kemajemukan menyusup dan merasuk ke dalam setiap dan seluruh ruang kehidupan, tak terkecuali dalam hal kepercayaan dan budaya. Pada sisi yang lain, kita pun merasakan bahwa pendidikan agama yang diberikan di sekolah-sekolah kita pada umumnya tidak menghidupkan pendidikan multikultural yang baik bahkan cenderung berlawanan. Akibatnya, konflik sosial sering kali di perkeras oleh adanya legitimasi keagamaan yang diajarkan dalam pendidikan agama di sekolah-sekolah daerah yang rawan konflik. Ini membuat konflik 
mempunyai akar dalam keyakinan keagamaan yang fundamental sehingga konflik sosial kekerasan semakin sulit di atasi, karena dipahami sebagai bagian dari panggilan agamanya. ${ }^{1}$

Bangsa Indonesia yang tengah berusaha untuk bangkit dari keterpurukannya akibat krisis multidimensi sangat memerlukan kerja kolaboratif dan koordinatif dari berbagai komponen untuk menggalang semua potensi bangsa, agar terjadi sebuah kerjasama yang efektif dan produktif. Namun, upaya-upaya seperti itu seringkali terhambat oleh adanya potensi-potensi konflik yang demikian banyak di negeri ini (agama, etnis, strata sosial, dsb). Salah satu potensi konflik yang mungkin dapat menghalangi proses pembangunan dan modernisasi di Indonesia adalah pemahaman Agama. Apalagi akhir-akhir ini nampaknya penafsiran agama telah diwarnai oleh berbagai bias kepentingan dan idiologi politik tertentu, yang mengakibatkan beberapa kelompok tertentu telah berani menghakimi kelompok-kelompok lain yang tidak sepaham sebagai kelompok sesat, murtad, kafir, bid'ah, dan berbagai sebutan lain yang mengkonotasikan ketidakpantasan kelompok lain tersebut untuk eksis dan hidup berdampingan secara damai dengan mereka.

Adapun hal yang mendorong adanya kekerasan di Indonesia antara lain faktor kegagapan budaya, adanya akumulasi kebencian dalam masyarakat yang diawali dengan anggapan yang salah terhadap pemeluk agama lain. Masyarakat Indonesia sendiri telah terjebak dalam budaya intoleran, tidak mampu menerima pluralitas tradisi, cara berkomunikasi, cara pandang terhadap kehidupan dan tekanan terhadap tradisi. ${ }^{2}$

${ }^{1}$ Mumammad Yusri, FM, "Prinsip Pendidikan Multikulturalisme Dalam Ajaran Agama-agama Di Indonesia", Jurnal Kependidikan Islam, Jurusan Kependidikan Islam Fakultas Tarbiyah UIN Sunan Kalijaga, Vol. 1, No 2 (Juli-Desember, 2008), hlm. 3-4.

${ }^{2}$ Nurul Huda, Multikulturalisme Dalam Bayang-bayang Histografi Resmi Nasional dalam Sururin (ed) Nilai-Nilai Pluralisme Dalam Islam, (Bandung: Nuansa, 2005), hlm. 165. 
Berkembangbiaknya Islam fundamental radikal berangkat dari suatu pemahaman keagamaan yang cenderung bersifat absolutisme pemikiran yang mendasarkan diri pada teks klasik Islam, karena penekanan pada teks semacam itu, maka membawa implikasi langsung terhadap tindakan politiknya, karena orientasi keberagamannya sangat mengutamakan skripturalisme absolute, sikap mereka umumnya sangat ekstrem (termasuk katagori Islam yang menakutkan). Tindakan-tindakan politik dari kelompok ini selain mengedepankan simbol-simbol keagamaan tetapi juga sering berakhir "anarkis".

Dalam perkembangannya, terdapat dua bentuk berbeda dari gerakan Islam radikal di Indonesia. Pertama, gerakan Islam yang masih dalam bentuk seperti yang berkembang didaerah Jawa Tengah. Beberapa diantaranya adalah Hizbul Tahrir Indonesia (HTI), tarbiyah-ikhwanul musliminan dan gerakan salafi-wahabi. Kedua, gerakan Islam radikal yang sudah bermetamorfosis, meskipun secara ideologis sangat sesuai dengan gerakan Islam radikal transnasional di Indonesia. Beberapa contoh dapat disebut, misalnya Front Pembela Islam (FPI), Lasykar Jihad (LJ), Majelis Mujahidin Islam (MMI), dan sebagainya. ${ }^{3}$

Melihat berbagai konflik dan penyebabnya di Indonesia umat Islam sebagai umat yang terbesar di Indonesia perlu memiliki pemahaman yang mendasar dan wawasan yang luas mengenai kehidupan bersama dalam berbagai perbedaan yang ada. Dalam hal ini terdapat sebuah paradigma yang dikenal dengan paradigma PAI berbasis inklusif dalam kehidupan sosial beragama multikultur. Secara umum paradigma PAI berbasis inklusif ini adalah sebuah pemikiran yang bersifat terbuka. Inklusifisme Islam ini identik dengan sikap keterbukaan, toleransi dan semangat bekerjasama baik antar pemeluk agama Islam maupun dengan pemeluk agama lain. Salah satu tokoh besar yang menggagas hal ini adalah KH. Abdurrahman Wahid.

${ }^{3}$ Rubaidi, Radikalisme Islam, Nabdlatul Ulama, (Yogyakarta, Logung Pustidaka, 2010 ), hlm. 65. 
Membangun paradigma pendidikan agama Islam berbasis inklusif dalam kehidupan sosial beragama multikultur menurut penulis sangat penting dan mempunyai nilai kontribusi pemikiran yang besar dalam memahami pendidikan Islam dalam kaitannya dengan masalah-masalah peradaban dan kemanusiaan yang dihadapi manusia Indonesia saat ini khususnya masalah kekerasan yang disebabkan oleh perbedaan pemahaman ajaran agama maupun perbedaan agama itu sendiri, kemiskinan, kebodohan dan keterbelakangan. Hal ini menjadi solusi yang relevan, penting dan menarik karena berusaha mencari terobosan-terobosan baru dalam rangka mensintesiskan wawasan keislaman dengan konteks keindonesiaan untuk mewujudkan kohesi dengan realitas dan konsepsi Indonesia sebagai Negara Bangsa.

\section{B. Pembahasan}

\section{Pendidikan Islam}

Pendidikan Islam menurut Ibnu Miskawaih dalam kitabnya Tahzibul Ablak adalah suatu usaha untuk mewujudkan pribadi susila, mempunyai watak yang luhur atau berbudi pekerti mulia. Sedangkan menurut al-Ghazali pendidikan Islam suatu proses kegiatan yang sistematis untuk melahirkan perubahan yang progresif pada tingkah laku manusia, yaitu menghilangkan akhlak yang buruk dan menanamkan akhlak yang baik. ${ }^{4}$

Pendidikan Islam merupakan usaha sadar untuk mengarahkan pertumbuhan dan perkembangan anak dengan segala potensi yang dianugerahkan Allah kepadanya agar mampu mengemban amanat dan tanggung jawab sebagai khalifah Allah di bumi dalam pengabdiannya kepada Allah. ${ }^{5}$

Menurut Abdurrahman Wahid pendidikan Islam yang inklusif adalah terkait konsep pembaharuan pendidikan Islam

${ }^{4}$ Busyairi Madjidi, Konsep Kependidikan Para Filosof Muslim, (Yoyakarta: Al Amin Press, 1997), hlm. 86.

5 Abdul Rachman Shaleh, Pendidikan Agama dan Pendidikan Keagamaan : Visi,Misi dan Aksi, (Jakarta: PT. Gemawindu Pancaperkasa, 2000), hlm. 4. 
dan modernisasi pendidikan Islam. Ajaran formal Islam itu harus diutamakan dan kaum muslimin harus dididik mengenai ajaran-ajaran agama mereka, dan dalam ini yang perlu dirubah adalah cara menyampaikan kepada peserta didik sehingga mereka mampu memahami dan mempertahankan kebenaran. Hal ini memiliki validitas sendiri, dapat dilihat dari kesungguhan anak muda muslim terpelajar,untuk menerapkan apa yang mereka anggap sebagai ajaran-ajaran yang benar tentang Islam. ${ }^{6}$

Implikasi keterangan di atas, kurikulum pendidikan Agama Islam mestilah mencakup topik-topik seperti: toleransi, perbedaan ethno-kultural dan agama, bahaya diskriminasi, penyelesaian konflik dan mediasi, HAM, demokrasi, kemanusiaan universal dan subjek-subjek lain yang relevan. ${ }^{7}$ Di samping tematema tambahan di atas, topik-topik yang selama ini ada, seperti konsep ketuhanan, konsep tentang manusia, konsep tentang agama, dan sumber ajaran islam misalnya, dapat dikupas dengan tetap mengedepankan paradigma inklusif.

Salah satu ciri paradigma inklusif dalam uraian topik-topik materi agama yang umum adalah pemaparan yang dilakukan secara terbuka dan dialogis. Artinya, dalam setiap tema dipaparkan semua perspektif yang terkait dengan pemahaman tema tersebut. Ambil contoh, ketika menjelaskan tentang wahyu dan alQur'an, maka kita tidak hanya menampilkan pandangan yang mengatakan bahwa ia adalah kalam Allah yang diturunkan laf̧̌ban wa ma'nan, dengan memberikan pandangan lain yang mungkin berbeda secara diametral dengan pandangan sebelumnya. ${ }^{8}$

${ }^{6}$ Abdurrahman Wahid, Islamku Islam Anda Islam Kita, Jakarta: Wahid Institute, 2006), hlm. 225.

${ }^{7}$ Syamsul Ma'arif, "Islam dan Pendidikan Pluralisme", makalah dipresentasikan pada Annual Conference Kajian Islam di Lembang 26-30 Nopember 2006, hlm. 15.

${ }^{8}$ Misalnya pendapat Mu'tazilah yang mengatakan bahwa al Qur'an diturunkan ma'nan saja sedangkan lafaz nya dari Nabi. Atau pandangan yang mengatakan bahwa Al Quran adalah kalam Allah dalam hal makna dan gagasannya, sedangkan format kebahasaannya adalah makhluk karena merupakan produk budaya Arab, lihat: Sahrur, Al Qur'an wa Al Kitab, (Beirut: Syarikah al Mathbu'at, 
Semua pandangan disampaikan lengkap dengan argumennya masing-masing dan penjelasan tentang konteks yang mendasari munculnya pandangan seperti itu, tanpa harus menghakimi atau memihak salah satu pandangan tersebut.

Keterangan di atas menunjukkan bahwa pendidikan agama semestinya menyadarkan peserta didik bahwa perbedaan perlu dilihat sebagai anugerah, tidak dilihat sebagai pilihan yang memberi alternatif untuk segera menyudahi perbedaan tersebut semisal dengan ideologisasi Islam yang mengarah pada upaya-upaya menjadikan Islam sebagai ideologi alternatif terhadap Pancasila. ${ }^{9}$ Sekiranya perbedaan dianggap anugerah, maka pendidikan agama mengemban tanggungjawab mendorong prakarsa dialog dan komunikasi positif dalam rangka mewujudkan saling memahami, saling menghargai, dan saling mempercayai agar keragaman dan perbedaan tidak menuai malapetaka.

\section{Pendidikan Islam Perspektif Inklusifisme}

Pendidikan Islam yang dilaksanakan dengan dibarengi inklusifisme akan mampu menjawab tantangan tersebut. Inti dari inklusifisme adalah adanya keterbukaan terhadap berbagai perbedaan yang ada. Dengan adanya inklusifisme ini kehidupan yang harmonis dalam masyarakat dapat tercapai. Pendidikan Islam yang inklusif sesuai dengan pandangan al-Qur'an tentang sikap inklusif dalam beragama yang terdapat pada Q.S. al-Baqarah [02]: 256 berikut ini:

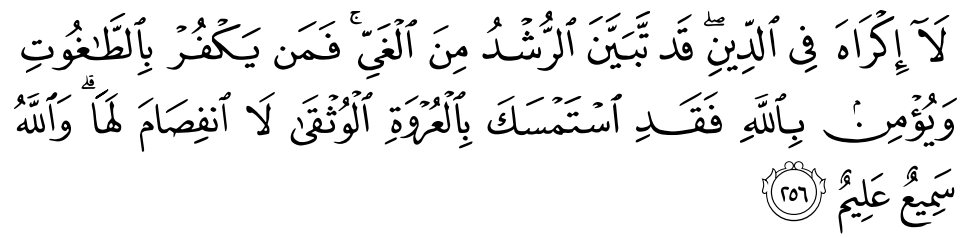

"Tidak ada paksaan untuk (memasuki) agama (Islam); Sesunggubnya telah jelas jalan yang benar daripada jalan yang sesat. karena itu Barangsiapa yang

2000), hlm. 71-73.

${ }^{9}$ Lihat M. Syafi'i Anwar, "Kata Pengantar" dalam Abdurrahman Wahid, Islamku, Islam Anda, Islam Kita: Agama Masyarakat Negara Demokrasi, (Jakarta: The Wahid Institute, 2006), hlm. xvi. 
ingkear kepada Thaghut dan beriman kepada Allah, Maka Sesunggubnya ia telah berpegang kepada bubul tali yang Amat kuat yang tidak akan putus. dan Allab Maha mendengar lagi Maha mengetahui. '"10

Sesungguhnya telah jelas jalan yang benar dari pada jalan yang sesat." Pendidikan Islam inklusif juga sesuai dengan alQur'an surat al- Baqarah ayat 62 yang menjelaskan pengakuan al-Qur'an atas eksistensi agama-agama lain:

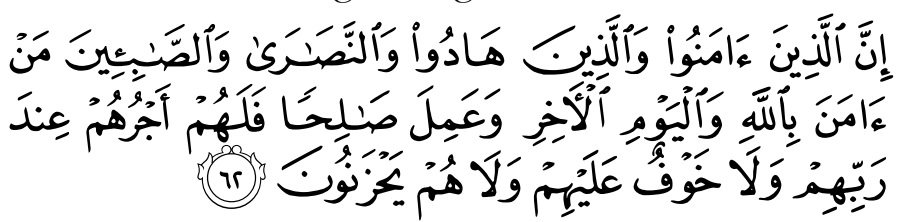

"Sesunggubnya orang-orang mukmin, orang-orang Yabudi, orang-orang Nasrani dan orang-orang Shabiin, siapa saja diantara mereka yang benarbenar beriman kepada Allah, hari kemudian dan beramal saleh, mereka akan menerima pahala dari Tuban mereka, tidak ada kekhawatiran kepada mereka, dan tidak (pula) mereka bersedib hati.” (Q.S. al-Baqarah [02]: 62). ${ }^{11}$

Merujuk pada kedua ayat di atas, pendidikan Islam yang inklusif penting dilaksanakan karena melihat kondisi sosial agama di ndonesia. Dimana berbagai agama berkembang dalam kehidupan masyarakatnya. Ada beberapa langkah konkrit yang dapat dilakukan untuk menanamkan sikap inklusif ini dengan melalui pendidikan yaitu memberikan pemahaman pada peserta didik tentang kehidupan beragama di Indonesia secara konstitusi telah diatur pada UUD 1945 pasal 29 tentang jaminan kemerdekaan beragama, memberikan pemahaman pada peserta didik bahwa membina kerukunan beragama bukan mencampuradukkan ajaran agama tetapi bekerjasama dalam kehidupan sehari-hari tanpa menganggu akidah agama masing-

${ }^{10}$ Departemen Agama RI, Al-Qur'an dan Terjemah, (Bandung: CV. Penerbit J-Art, 2005), hlm. 43.

11 Departemen Agama RI, Al-Qur'an dan Terjemah, (Bandung: CV. Penerbit J-Art, 2005), hlm. 11. 
masing, menjaga dan mengendalikan diri dari ucapan, sikap dan perbuatan yang menyinggung pemeluk agama lain. ${ }^{12}$

Seorang Guru Bangsa yang dikenal dengan nama K.H. Abdurrahman Wahid membagi Islam inklusif menjadi dua kelompok, dimana kelompok pertama berpendapat bahwa Islam seharusnya tidak menampilkan diri dalam bentuk yang eksklusif, Islam tidak menampilkan warna keislamannya tetapi mengintegrasikannya dalam kegiatan bangsa secara keseluruhan. Sedangkan pandangan dari kelompok kedua menginginkan diwujudkannya ajaran Islam dalam kehidupan berbangsa dan bernegara melalui pranatanegara. ${ }^{13}$

Pemikiran Abdurrahman Wahid berada dalam kategori pertama yang menentang Islam yang eksklusif dan berusaha mengajak umat Islam untuk mengembangkan sikap eklektik yaitu daya serap positif yang tinggi terhadap dunia luar yang memberi manfaat terhadap umat Islam. Abdurrahman Wahid berusaha mengkonteksualisasikan pemikiran Islam tradisionalnya dalam kehidupan. Hal tersebut melahirkan pribumisasi Islam yang merupakan pemahaman terhadap nash dikaitkan dengan masalah bangsa dan negara. Pribumisasi adalah upaya rekonsiliasi antara budaya dan agama. Namun menurutnya hal ini bukanlah suatu upaya jawanisasi atau sinkretisme ajaran Islam. Pribumisasi dimaksudkan untuk mempertimbangkan kebutuhan-kebutuhan lokal dalam merumuskan hukum-hukum agama tanpa mengubah hukum itu sendiri. ${ }^{14}$

Salah satu contohnya adalah kasus assalamu'alaikumnya Abdurrahman Wahid. Menurutnya ucapan salam dalam sholat memang wajib hukumnya tetapi secara budaya ucapan salam bisa diganti dengan selamat pagi dan lain sebagainya. Hal ini sama

${ }^{12}$ Zaidan Djauhary, Pedoman Dasar Kerukunan Hidup Beragama, Jakarta: Proyek Pembinaan Kerukunan Hidup Beragama, 1984), hlm. 3-6.

${ }^{13}$ Abdurrahman Wahid, Pribumisasi Islam, dalam Muntaha Azhari dan Abdul Mun"im Saleh (ed), Islam Indonesia Menatap Masa Depan, (Jakarta : P3M, 1989), h. 82-83.

${ }^{14}$ Ibid., hlm. 82-83. 
dengan shobabul khoir dalam bahasa Arab yang bisa digunakan oleh masyarakat di daerah Arab. Dengan demikian selamat pagi sebenarnya merupakan bentuk pribumisasi dari assalamu'alaikum dalam konteks budaya Indonesia. Dengan cara seperti ini menurut Abdurrahman Wahid akan menampung dua kebutuhan yang kita rasakan dalam kehidupan sehari-hari. Pertama, adaptasi kultural kepada adat istiadat kita selama ini. Kedua, kebutuhan untuk memelihara ajaran formal agama. ${ }^{15}$

Berkaitan dengan pemikiran Islam perspektif inklusifnya Abdurrahman Wahid memiliki visi yang dimulai dari pluralisme. Pluralisme bukan hanya sebagai sesuatu yang buman tetapi juga karunia yang bersifat permanen, karena tanpa pluralisme sejarah dan peradaban manusia tidak akan produktif, bahkan akan kehilangan perspektifnya yang dinamis dan dialektis. Bagi Abdurrahman Wahid tegaknya pluralisme masyarakat bukan hanya terletak pada suatu pola hidup berdampingan secara damai, karena hal demikian masih rentan terhadap munculnya kesalahpahaman antar kelompok dalam masyarakat yang pada saat tertentu bisa menimbulkan disintegrasi. Lebih dari itu, penghargaan terhadap pluralisme berarti adanya kesadaran untuk saling mengenal dan berdialog secara tulus sehingga kelompok yang satu dan lainnya saling memberi dan menerima. ${ }^{16}$

Hal di atas menunjukkan perlu adanya anjuran pada pemeluk agama agar kembali pada nilai-nilai universal agama, yaitu pembebasan berupa tanggung jawab sosial dan berdasarkan prinsip-prinsip kemanusiaan. Agama digunakan untuk memberdayakan masyarakat dan memiliki tujuan yang lebih universal seperti penegakan HAM, keadilan sosial dan demokrasi. Peran agama Islam sebagai agama mayoritas di Indonesia sangat menentukan demi tercapainya kehidupan yang harmonis antar

${ }^{15}$ Ibid., hlm. 83.

${ }^{16}$ Abdurrahman Wahid, "Pluralisme Agama Dan Masa Depan Indonesia" makalah pada Seminar Agama dan Masyarakat, Universitas Kristen Satya Wacana, Salatiga, 20 November 1992 sebagaimana dikutip oleh Umaruddin Masdar, hlm. 45. 
umat beragama. Oleh karena itu internalisasi dan aktualisasi ajaran agama Islam yang menekankan watak inklusif dan toleran sangat diperlukan dalam membangun paradigma pendidikan Islam berbasis inklusif dalam kehidupan sosial beragama multikultur.

Karena keterlibatan Abdurrahman Wahid secara aktif dalam berbagai kegiatan dengan kalangan non muslim, ia sering kali mendapat kritikan keras dari para penentangnya. Menurut mereka Abdurrahman Wahid dianggap terlalu dekat dengan kalangan non muslim daripada dengan kalangan muslim sendiri. Sedangkan menurut mereka seharusnya pengikut nabi Muhammad itu keras terhadap orang kafir dan santun kepada sesamanya. Kritik tersebut di sandarkan pada (QS. Al Fath [48]: 29)

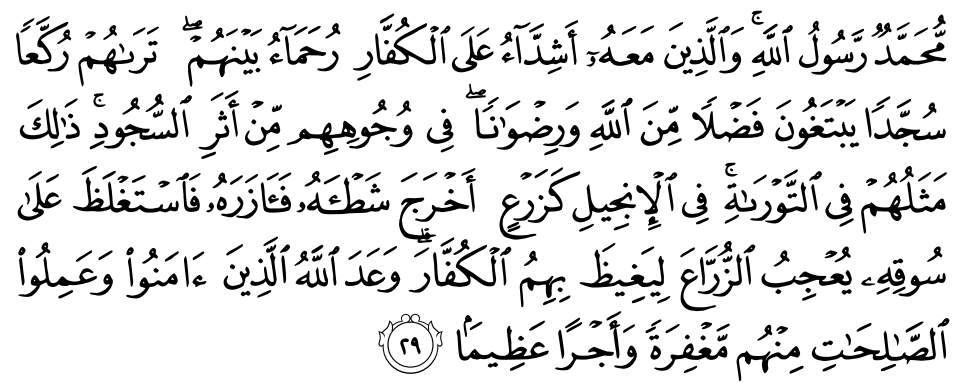

"Mubammad itu adalab utusan Allah dan orang-orang yang bersama dengan Dia adalah keras terhadap orang-orang kafir, tetapi berkasih sayang sesama mereka. kamu Lihat mereka ruku> dan sujud mencari karunia Allab dan keridhaan-Nya, tanda-tanda mereka tampak pada muka mereka dari bekas sujud[1406]. Demikianlah sifat-sifat mereka dalam Taurat dan sifat-sifat mereka dalam Injil, Yaitu seperti tanaman yang mengeluarkan tunasnya Maka tunas itu menjadikan tanaman itu kuat lalu menjadi besarlah Dia dan tegak. Lurus di atas pokoknya; tanaman itu menyenangkan hati penanam-penanamnya karena Allah hendak menjengkelkan hati orang-orang kafir (dengan kekuatan orang-orang mukmin). Allah menjanjikan kepada orang-orang yang beriman dan mengerjakan amal yang saleh di antara mereka ampunan dan pabala yang besar. "17

Namun kritik tersebut menurut Abdurrahman Wahid memiliki kekeliruan yang serius. Menurutnya yang dimaksud

${ }^{17}$ Departemen Agama RI, Alqur'an dan Terjemah, (Jakarta: CV. Penerbit J-Art, 2005), h. 516. 
dengan orang kafir dalam ayat tersebut bukanlah orang non muslim melainkan orang kafir yang memerangi agama Islam yang dalam konteks ayat tersebut adalah orang kafir Mekah. ${ }^{18}$ Selain itu Abdurrahman Wahid juga mengkritik pemahaman kaum muslim yang membenarkan sikap dan tindakan anti toleransi dengan mengutip ayat:

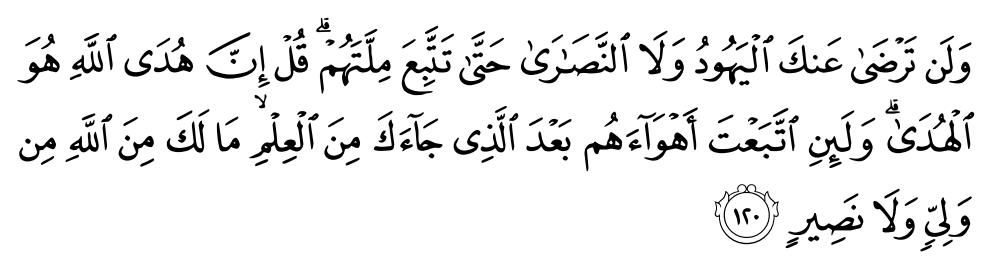

"Orang-orang Yahudi dan Nasrani tidak akan senang kepada kamu bingga kamu mengikuti agama mereka. Katakanlah: "Sesunggubnya petunjuk. Allah Itulah petunjuk (yang benar)». dan Sesunggubnya jika kamu mengikuti kemanan mereka setelah pengetahuan datang kepadamu, Maka Allab tidak. lagi menjadi pelindung dan penolong bagimu." (QS. al-Baqarah [02]: 120). ${ }^{19}$

Kata "tidak senang" dalam ayat tersebut bagi kalangan eksklusif dianggap melawan atau memusuhi dan dikaitkan dengan aktivitas gereja-gereja, pengabaran injil dan sebagainya. ${ }^{20}$ Sedangkan Abdurrahman Wahid mengungkapkan bahwa Kristen dan Yahudi tidak bisa menerima konsep dasar Islam, itu sudah tentu. Sebab kalau mereka mau menerima, itu artinya bukan Kristen atau Yahudi lagi. Maksudnya jawaban kebalikan terhadap ayat tadi juga bisa kita buat sama : Wa lan tardho, dst. Kita tidak rela dengan Yahudi dan Nasrani, ke'Tuhanannya, sebab memang sudah beda. Tapi itu tidak berarti ada permusuhan. ${ }^{21}$

18 Abdurrahman Wahid,"Dialog Agama dan Masalah Pendangkalan Agama" dalam komaruddin Hidayat dan Ahmad Gaus AF (ed), Passing Over melintasi Batas Agama, (Jakarta: Gramedia Pustaka Utama, 1998), hlm. 53.

${ }^{19}$ Departemen Agama RI, Alqur'an dan Terjemah, (Jakarta: CV. Penerbit J-Art, 2005), hlm. 20.

${ }^{20}$ Abdurrahman Wahid,"Dialog Agama dan Masalah Pendangkalan Agama" dalam komaruddin Hidayat dan Ahmad Gaus AF (ed), Passing Over melintasi Batas Agama, (Jakarta: Gramedia Pustaka Utama, 1998), hlm. 53.

${ }^{21}$ Abdurrahman Wahid,"Dialog Agama dan Masalah Pendangkalan Agama" dalam komaruddin Hidayat dan Ahmad Gaus AF (ed), Passing Over 
Kebebasan manusia merupakan syarat bagi tegaknya demokrasi. Kebebasan ini mencakup pula kebebasan manusia memilih agama. Namun di sisi lain perpindahan agama menurut hukum Islam berarti penolakan kepada konsep Allah sebagai Zat Yang Maha Benar (taubid) dan sebagai hukumannnya adalah hukum mati. Pemahaman agama seperti ini tentu bertentangan dengan demokrasi dan tidak memberi kesempatan untuk raguragu. Abdurrahman Wahid menyebut pemahaman "yang formalistik" terhadap ajaran agama. ${ }^{22}$

Hak individu warga masyarakat ditegakkan dalam demokrasi dan salah satu hak itu adalah kebebasan beragama. Menurut Abdurrahman Wahid hal itu menunjukkan bahwa fungsi transformatif yang dibawa agama bagi demokratisasi kehidupan masyarakat harus bermula dari transformasi intern agama yaitu dengan merumuskan kembali pandangan-pandangan agama tentang martabat manusia. ${ }^{23}$ Dalam Islam sendiri umat bebas membandingkan keyakinannya dengan keyakinan lain untuk membuktikan kebenaran konsep keyakinannya sendiri. Islam memberi peluang bagi kebenaran melalui proses dialektif. Hal ini memerlukan derajat toleransi yang tinggi.

Dari sini tampak Abdurrahman Wahid melakukan pergeseran teologis dari eksklusif ke teologi inklusif, dari teologi profesional ke teologi praktis, dari membela Tuhan ke membela manusia. Sehingga akan lebih membela kaum lemah (minoritas) dengan tanpa kekerasan daripada membela kekuasaan. Abdurrahman Wahid menghendaki dirumuskannya ideologi sosial yang revolusioner guna memerankan agama dalam pengembangan masyarakat. Ideologi itu harus mengandung satu keyakinan akan perlunya masyarakat yang lebih egalitarian,

melintasi Batas Agama, (Jakarta: Gramedia Pustaka Utama, 1998), hlm. 53.

22 Abdurrahaman Wahid, Membangun Demokrasi, (Bandung: PT. Rosdakarya, 1999), hlm.24.

${ }^{23}$ Abdurrahman Wahid, Mengurai Hubungan Agama dan Negara, (Jakarta: PT Gramedia Widiasarana Indonesia, 1999), hlm. 167-168. 
struktur ekonomi yang lebih mementingkan rakyat kecil dan orientasi yang lebih populistik. ${ }^{24}$

Pemikiran teologis Abdurrahman Wahid ini berbeda dengan pendapat umat Islam pada umumnya. Beliau lebih bisa menerima kebebasan beragama dalam rangka penegakan demokrasi daripada membela bangunan teologi sendiri. Bagi umat Islam pada umumnya pemikiran Abdurrahman Wahid ini dianggap tabu, tapi bagi Abdurrahman Wahid sendiri pencarian individu menuju kebenaran harus tetap dihormati. Ia sangat yakin dan teguh bahwa Islam adalah tetap yang terbaik, tetapi tidak berarti menghalangi pemikiran bahwa agama lain pun baik. Baginya setiap agama ditentukan oleh keikhlasan dan kesungguhan pemeluknya. Islam mengakui lima jaminan keselamatan dasar yaitu jaminan keselamatan fisik, jaminan keselamatan keyakinan, jaminan keselamatan harta benda, jaminan keselamatan profesi, dan jaminan keselamatan keturunan. Jaminan dasar atas keyakinan berdasar sikap saling menghormati akan mendorong sikap tenggang rasa dan saling pengertian yang tinggi. ${ }^{25}$

Sikap toleransi di atas menurut Abdurrahman Wahid telah dicontohkan Islam dengan transformasi sosial dalam skala massif atau ketidakadilan wawasan hidup jahiliyah yang dianut masyarakat arab pada waktu itu. Dengan tauhid Islam menegakkan penghargaan atas perbedaan pendapat dan benturan keyakinan. Selanjutnya mengenai hubungan antar agama di Indonesia menurut Abdurrahman Wahid dipengaruhi oleh pemikiran keagamaan di kalangan umat beragama itu sendiri. Hal ini juga tampak jelas dalam hubungan muslimin dengan umat beragama lain. Islam datang ke Indonesia dalam bentuk dan corak yang heterogen. Heterogenitas asal-usul Islam di Indonesia ini, menunjukkan pula variasi sangat tinggi dalam pengalaman

24Ibid., hlm. 167-168.

25 Abdurrahman Wahid, "Hubungan Antar Agama Dimensi InternalEksternal” dalam Sudiarjo (ed), Dialog Intra Religius, (Yogyakarta: Kanisius, 1994), hlm. 6. 
menjalani hubungan antar agama yang dibawa oleh kaum muslimin ke negeri ini. ${ }^{26}$

Jalan untuk menumbuhkan situasi kondusif seperti itu adalah melalui dialog. Namun harus perlu diketahui dahulu wilayah-wilayah mana yang menjadi urusan agama masing-masing dan mana wilayah-wilayah yang terbuka untuk didialogkan. Dialog tersebut dimaksudkan untuk mencari titik temu, karena itu sangat dibutuhkan adanya kesadaran untuk menghormati konsep agama lain. Penganut suatu agama tidak semestinya membicarakan konsep agama lain secara negatif. ${ }^{27}$

Memahami agama lain sangat dibutuhkan untuk menciptakan kerukunan antar umat beragama. Memahami agama lain memerlukan sikap arif dan bijaksana. Hal ini memang tak mudah karena pemahaman agama lain terkadang tidak sesuai dengan pemahaman agama sendiri. Hal tersebut hanya bisa dilakukan dengan sikap terbuka. Sikap terbuka hanya bisa ditumbuhkan dengan pluralisme. Jika pluralisme dapat dipahami sebagai kehendak Tuhan yang tak mungkin diingkari, pluralisme dapat diterima dengan sikap optimis dan positif.

Dengan demikian akan dapat mewujudkan komunikasi sosial yang terbuka, sehat dan aman. Untuk itu dialog yang intensif juga diperlukan. Sangat disayangkan sampai sekarang masih banyak umat beragama yang menganggap mengenal umat lain itu tidak penting. Mereka mengekspresikan kesalahan pengalaman mereka terhadap keTuhanan agama lain, atau bahkan menghina agama lain. Padahal menghina Tuhan yang dianggap milik agama lain sama juga menghina Tuhan sendiri karena pada hakikatnya Tuhan itu satu, hanya berbeda dalam konseptualisasinya. ${ }^{28}$

Sebagai solusi atas keeksklusifan, ada baiknya mencari titik temu dari segala perbedaan, bukan menonjolkan perbedaan

${ }^{26}$ Ibid., hlm. 6.

${ }^{27}$ Abdurrahman Wahid, Mengurai Hubungan Agama dan Negara, (Jakarta: PT Gramedia Widiasarana Indonesia, 1999), hlm. 179.

${ }^{28}$ Abdurrahman Wahid, Mengurai Hubungan Agama dan Negara, hlm.178. 
itu sendiri. Perlu adanya upaya dalam mencari titik temu tersebut yang datang dari luar lingkungan, yaitu sikap eklektik yang harus ditanamkan pada umat beragama pada umumnya dan umat Islam khususnya, sehingga menjadi keharusan bagi umat sekarang agar unsur-unsur utama keagungan dan kemegahan peradaban Islam masa lampau.

Dalam konteks wawasan keindonesiaan, Islam hanyalah salah satu dari sekian pandangan hidup yang ada di dalamnya. Pluralitas agama, tradisi, budaya dan pandangan hidup merupakan sesuatu yang sudah mapan dalam bangunan keindonesiaan. Karena itu, setiap agama termasuk agama Islam seharusnya difungsionalisasikan dalam posisi seimbang dan timbal balik. Tidak ada yang mendominasi dan didominasi. Dalam konteks ini Abdurrahman Wahid memilih mengimplementasikan Islam sebagai etika sosial dalam kehidupan bernegara. Islam tidak berfungsi sebagai hipotesa operatif, tetapi sebagai sumber inspiratif bagi kehidupan masyarakat. Penekanan Islam sebagai etika sosial ini bukan saja akan membuat Islam terbebas dari keharusan-keharusan ideologis formal yang muncul jika Islam dijadikan sebagai ideologi negara sekaligus melindungi realitas pluralistik bangsa itu sendiri. ${ }^{29}$

Islam sebagai etika sosial berarti Islam bersifat komplementer dalam kehidupan negara. Menempatkan Islam sebagai etika sosial merupakan konstruk yang menyeimbangkan antara keharusan mengambil nilai-nilai positif dari proses sekularisasi (bukan sekularisme) dan spiritualitas operatif sebagai manifestasi ketaatan terhadap ajaran agama. ${ }^{30}$ Sebagai etika sosial keIslaman dapat termanifestasi dalam banyak wajah. Pertama Islam akan menjadi agama yang terbuka, karena sebagai etika

29 Abdurrahman Wahid, "Beberapa Aspek. Teoritis dari Pemikiran Politik dan Negara Islam” dalam Imron Hamzah dan Choirul Anam (Ed), Abdurrahman Wahid Diadili Kiai-kiai: Sebuah Dialog Mencari Kejelasan, (Surabaya : Jawa Pos, 1989), hlm.106.

30 M. Hanif Dhakiri, 41 Warisan Kebesaran Gus Dur, (Yogyakarta: LkiS, 2010), hlm. 102. 
Islam terhindar dari kekakuan ajaran formalnya. Kedua, Islam menjadi sumber inspirasi bagi banyak golongan karena etika pada dasarnya bersifat universal. Ketiga, Islam akan menyatu sebagai bagian dari perubahan masyarakat secara Keseluruhan. ${ }^{31}$

Selain sebagai etika sosial, Islam juga merupakan sebuah sistem kemasyarakatan. Maksudnya studi tentang sistem kemasyarakatan bukanlah struktur kehidupannya yang bersifat organisatoris belaka melainkan pengaruh tata kehidupan masyarakat atas tingkah laku para warganya. Dengan demikian yang dikaji adalah sebuah proses timbal balik antara tata kehidupan dan tingkah laku para warga sebagai dua komponen yang masingmasing berdiri sendiri, tetapi sekaligus interindependen dengan masyarakat lain. ${ }^{32}$

Pemahaman yang berkembang dikalangan kaum muslimin selama berabad-abad jelas sekali akan bervariasi/beraneka ragam, tergantung dari faktor-faktor geografis, historis, dan sosiologis yang mempengaruhi pemahaman masing-masing. Sebab-sebab utama dari pemahaman seperti itu adalah mentahnya pencernaan gagasan-gagasan dan pengetahuan yang diterima dari luar dan faktor perkembangan historis tentang kemunduran sosio-politis dan peningkatan sosio-kultural.

Terkait dengan kehidupan agama yang ada di Indonesia, semua umat dapat dilihat dari dua aspek yaitu aspek kemasyarakatan dan aspek perorangan. Kedua aspek tersebut berkaitan erat, tetapi pada saat yang sama dapat dibedakan dengan jelas satu dari yang lainnya. Kehidupan agama yang bersifat perorangan sangat berkaitan dengan pengalaman pribadi seseorang, persepsinya tentang sesuatu yang gaib yang hadir dalam kehidupannya dan intensitas pengalaman dengan sesuatu yang gaib itu sehingga akhirnya menghasilkan suatu keharuan, kesyahduan, ketakutan ataupun ketundukan yang tulus kepada

\footnotetext{
${ }^{31}$ Ibid., hlm. 103.

${ }^{32}$ Abdurrahman Wahid, Muslim Di Tengah Pergumulan, (Jakarta: Leppenas, 1983), hlm. 10.
} 
sesuatu yang gaib dan supernatural yang berada di luar jangkauan pemahaman akalnya tetapi sepenuhnya dapat dirasakannya hadir secara penuh dalam kehidupan itu sendiri. ${ }^{33}$

Pengalaman yang begitu intens dapat timbul dari keputusasaan hidup, ketakutan yang luar biasa akan timbul suatu hal, kekecewaan sangat besar yang ditemui, kesedihan sangat dalam yang dialami, ataupun justru karena kegembiraan dan rasa terima kasih yang tulus. Ia dapat juga muncul dari ketidak mengertian, kebingungan, ataupun masalah yang lainnya. Sehingga sesuatu yang tidak terduga yang mempengaruhi hidup secara mendasar, sering kali membawa kesadaran beragama yang lebih tinggi dari yang dialami.

Keislaman dan keindonesiaan harus berjalan seiring. Sinergi keislaman dan keindonesiaan telah menciptakan karakter Islam yang moderat, toleran dan tidak berlebihan. Identitas nasionalisme-religius pada dasarnya merupakan kristalisasi diri gagasan sejarah, tradisi Islam Indonesia yang moderat, terbuka dan dialogis. Posisi ideologis dengan perspektif teologis yang kental ini selaras dengan gagasan cerdas nan agung founding fathers Indonesia yang merumuskan Pancasila sebagai dasar negara. Pilihan yang didukung oleh ulama-ulama Ablussunah wal Jamaah itu sangat relevan dengan realitas kebangsaan Indonesia yang majemuk dan multikultural. Abdurrahman Wahid percaya bahwa dalam hal perjuangan keagamaan, membesarkan agama bukan berarti harus mengecilkan agama orang lain. ${ }^{34}$

Perjuangan keagamaan yang sesungguhnya adalah perjuangan kemanusiaan yang mengedepankan cinta kasih, persaudaraan, dan kehendak untuk hidup secara damai. Kepentingan bersama suatu bangsa dengan demikian harus menundukkan kepentingan-kepentingan parsial yang sempit, yang justru aan merendahkan agama Islam dan kemanusiaan. Menempatkan kepentingan nasional diatas kepentingan parsial

\footnotetext{
${ }^{33}$ Ibid., hlm. 46.

${ }^{34}$ Ibid., hlm.33.
} 
apapun secara pasti merupakan perjuangan yang melandasi semangat kebersamaan yang tinggi.

Sesungguhnya Islam moderat, inklusif dan toleran tidak mengesampingkan agama, tetapi justru meluhurkannya. Hasil dari semuanya adalah perwujudan Indonesia yang adil dan makmur, demokratis dan sosial multikultural. Islam menjadi landasan etis bagi kehidupan berbangsa dan bernegara. Keyakinan terhadap Islam Indonesia yang moderat, toleran, dan anti diskriminasi itulah yang memungkinkan umat Islam Indonesia berkontribusi secara optimal dalam pelbagai proses penyelenggaraan negara dan kehidupan kebangsaan pada umumnya. Dengan Islam yang damai dan rabmatan lil alamin bisa menjadi pelindung dan pengikat berbagai agama dan keyakinan. Dan disinilah terlihat betapa luhurnya ajaran Islam.

\section{Pendidikan Islam Berbasis Inklusif Dalam Kehidupan Multikultur}

Ketika pendidikan Islam mencita-citakan terciptanya manusia dan kehidupan yang baru maka konsep manusia dan kehidupan yang Islami harus berpijak pada konsep fundamental tentang individu, masyarakat, dan dunia. Islam tidak mengkotakkotakkan antara individu, masyarakat, dan dunia. Dalam pandangan Islam, dunia yang baik berangkat dari masyarakat yang baik, dan masyarakat yang baik berawal dari individu yang baik.

Paradigma Pendidikan Agama Islam berbasis inklusif dalam kehidupan sosial beragama multikultur ini terbagi menjadi beberapa aspek yaitu aspek manusia, kurikulum dan metode pembelajarannya. Terkait dengan aspek manusia terdapat beberapa nilai yang harus dikembangkan yaitu:

\section{a. Nilai persamaan (sederajat)}

Islam menegaskan bahwa kesamaan individu adalah dasar martabat manusia. ${ }^{35}$ Persamaan manusia dalam ajaran Islam tidak mengenal suku, ras, dan warna kulit (Q.S. al-Hujurat [49]: 13).

${ }^{35}$ Machasin, "The Concept of Human Being", h. 10 dan 12; dalam 


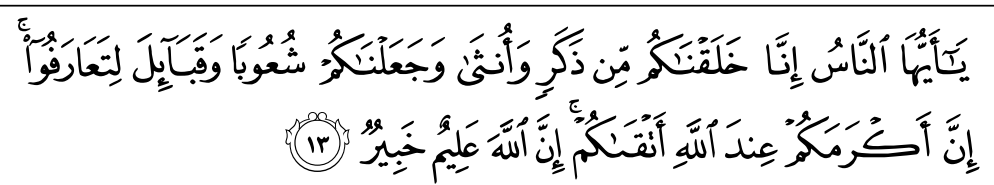

"Hai manusia, Sesungguhnya Kami menciptakan kamu dari seorang lakilaki dan seorang perempuan dan menjadikan kamu berbangsa - bangsa dan bersuku-suku supaya kamu saling kenal-mengenal. Sesunggubnya orang yang paling mulia diantara kamu disisi Allah ialah orang yang paling taqwa diantara Kamu. Sesunggubnya Allah Maha mengetabui lagi Maba Mengenal." 36

Ayat ini menegaskan bahwa nilai manusia hanya dibedakan oleh kualitas ketakwaannya kepada Allah. Kekuasaan mutlak dan transendensi Allah memberikan kemerdekaan kepada manusia dan membentuk konsep persamaan total kepada setiap orang. Persamaan ini menjadi sumbangan Islam bagi kebudayaan universal. Tak ada agama atau ideologi sebelum Islam yang menekankan dengan kuat tentang prinsip persamaan manusia sebagai dasar pola hubungan manusia. Tidak bolah satu kelompok mendoninasi dan melanggar hak kelompok lainnya. Demikian juga kelompok mayoritas tidak boleh menguasai kelompok minoritas. Disnilah penanaman nilai multikultural menjadi penting dalam pendidikan di Indonesia. Peserta didik hendaknya ditanamkan semangat bekerjasama dalam kesederajatan, kesamaan, dan tidak melakukan diskriminisasi atas dasar ras, etnis, agama, maupun gender.

Kata kunci dalam kehidupan berbangsa di Indonesia adalah adanya persamaan perlakuan untuk mendapatkan pengakuan atau dihormati keberadaannya, persamaan mendapatkan kesempatan, dan perlakuan yang sama atas hukum dan perlakuan hukum, apapun budaya, ras, etnis dan agama. Disinilah peserta didik bisa mengasah rasa sensitivitas terhadap kultur minoritas dan menggerakkan kelompok kultur yang mayoritas untuk punya

'Ali Khalil Abu al-'Ainain, Falsafah al-Tarbiyah al-Islamiyyah fi al-Qur'an al-Karim, pengantar: 'Abd al-Gani 'Abbud, (t.tp.: Dar al-Fikr al-'Arabi, 1980), hlm. 7.

${ }^{36}$ Departemen Agama RI, Alqur'an dan Terjemah, (Jakarta: CV. Penerbit J-Art, 2005), hlm. 518. 
perasaan dan sikap yang sama dengan kelompok atau kultur lainnya.

Inilah contoh persamaan etnis yang bisa menjadi inspirasi bagi peserta didik. Materi ini bisa dimasukkan kedalam mata pelajaran agama Islam baik secara prosedural melalui kurikulum maupun biden kurikulum.

\section{b. Nilai Demokrasi yang Substansial}

Menurut Kamus Besar Bahasa Indonesia, demokrasi diartikan sebagai gagasan atau pandangan hidup yang mengutamakan persamaan hak dan kewajiban serta perlakuan yang sama bagi semua warga negara. ${ }^{37}$

Dalam konteks pembelajarannya, pendidikan yang demokratis menuntut adanya interaksi antara peserta didik dan pendidik dalam bentuk egaliter dan equity (kesetaraan atau sederajat dalam kebersamaan). Dengan adanya kesetaraan ini, kebebasan berinisiatif, berbeda aspirasi dan pendapat, serta keadilan dalam pendidikan akan terakomodasi dengan baik. Karena itulah, dalam proses pembelajaran harus terdapat interaksi dua arah antara guru dan siswa.

\section{c. Nilai Kesetaraan Gender}

Konsep gender dipahami sebagai suatu dasar untuk menentukan perbedaan sumbangan laki-laki dan perempuan pada kebudayaan dan kehidupan kolektif. ${ }^{38}$ Terwujudnya kesetaraan dan keadilan gender ditandai dengan tidak adanya diskriminasi antara perempuan dan laki-laki, sehingga mereka memiliki akses, kesempatan berpartisipasi dan kontrol atas pembangunan dan memperoleh manfaat yang setara dan adil dari pembangunan. Secara historis telah terjadi dominasi laki-laki dalam segala lapisan masyarakat di sepanjang zaman, dimana perempuan dianggap

${ }^{37}$ Tim Penyusun Kamus Pusat Pembinaan dan Pengembangan Bahasa Departemen Pendidikan dan Kebudayaan, Kamus Besar Bahasa Indonesia, Jakarta: Balai Pustaka, 1989), hlm. 337.

${ }^{38}$ Wilson, T. H. Sex and Gender: Making cultural sense of Civilization, (New York: E. J. Brill, 1989), hlm. 2. 
lebih rendah daripada laki-laki. Dari sini muncullah doktrin ketidaksetaraan antara laki-laki dan perempuan. ${ }^{39}$

Akibat dari ketidakadilan gender ini banyak kaum perempuan yang minim mendapat kesempatan untuk berkarier ataupun terjun dalam dunia sosial dan keagamaan. Fenomena ini juga banyak terjadi dalam masyarakat Islam. Hal ini terjadi karena dalam agama Islam terdapat pandangan bahwa yang pantas dan boleh menjadi pemimpin hanyalah seorang laki-laki. Pandangan tersebut telah mengakar kuat dalam konsep dan pelaksanaan keberagaman sehari-hari umat Islam. Abdurrahman Wahid memberikan gagasan tentang gender. Hal ini dengan pemahamannya tentang persamaan manusia dalam lima hal pokok yang prinsipil dalam keagamaan yaitu perlindungan menganut kepercayaan dan agama, perlindungan atas nalar, perlindungan atas jiwa, perlindungan akan kehormatan dan perlindungan keberlangsungan keturunan dan harta benda. ${ }^{40}$ Terkait dengan hal tersebut Abdurrahman wahid memberikan penekanan kesamaan dan kesetaraan yang mendasar antara laki-laki dan perempuan serta hak-hak yang mereka yang vital. Menurutnya perempuan juga memiliki potensi untuk bisa melakukan peran yang selama ini dianggap hanya bisa dilakukan oleh para lelaki.

Kesetaraan gender merupakan salah satu hal wujud nyata dari adanya konsep Islam inklusif dalam kehidupan khususnya kehidupan sosial beragama. Hal ini dapat terlaksana dengan baik dengan adanya pemahaman yang baik tentang konsep tersebut. Pendidikan Islam merupakan sarana untuk mencapai hal tersebut terutama dalam hal keagamaaan.

${ }^{39}$ Asghar Ali Engineer, Hak-hak Perempuan dalam Islam, terj. Farid Wajidi dan Cici Farkha Assegaf, (Yogyakarta: Lembaga study Pengembangan Perempuan dan Anak, 1994), hlm. 55.

${ }^{40}$ Abdurrahman Wahid, Muslim di Tengah Pergumulan, Jakarta: Lappenas, 1981), hlm. 43. 
Terkait dengan nilai-nilai yang harus dikembangkan seperti yang telah disebutkan diatas pada proses pelaksanaan pendidikan maka terdapat dua aspek yang perlu diperhatikan yaitu :

\section{1) Aspek Guru}

Guru mempunyai peran strategis dalam rangka menyiapkan kader bangsa. Diakui atau tidak, guru akan selalu menjadi unsur penting yang menentukan berhasil atau tidaknya suatu pendidikan. Oleh karena itu maka guru selalu berperan dalam pembentukan sumberdaya manusia yang pontensial dibidang pembangunan bangsa dan negara. Guru adalah orang kedua setelah orang tua yang selalu mendidik dan mengawasi anak, untuk menuju cita-cita dan tujan hidupnya.

Guru merupakan seorang yang menempatkan agama sebagai nilai luhur yang membawa nilai kebenaran, keadilan, dan kesejahteraan. Guru adalah pribadi yang mengajarkan wawasan keagamaa masyarakat secara inklusif, toleran agar terwujud persaudaraan sejati lintas pemeluk agama, ikut serta mengembangkan dialog dan kerjasama antar agama dalam menanggulangi masalah manusia yang erta kaitannya dengan upaya memperkuat saling perngertian dan toleransi antar iman dan agama. ${ }^{41}$

Guru memberikan kemerdekaan sepenuhnya pada peserta didik untuk berkembang dan berikap kritis sesuai dengan ajaran Islam. Guru harus mampu membentuk kesadaran kritis peserta didik untuk bisa menghargai perbedaan yang terjadi di tengah masyarakat majemuk. Guru yang menghargai pluralitas dan toleransi antar umat beragama. Guru yang tidak fanatik pada suatu paham atau aliran tertentu. Guru harus berdiri di semua golongan masyarakat.

${ }^{41}$ Gus Dur, Partai Kebangkitan Bangsa, (Jakarta: PKB Pres, 2005), hlm. 30 . 


\section{2) Aspek Peserta Didik}

Dilihat dari segi kedudukannya peserta didik adalah makhluk yang sedang berada dalam proses perkembangan dan pertumbuhan menurut fitrahnya masing-masing. Mereka memerlukan bimbingan dan pengarahan yang konsisten menuju kearah titik optimal kemampuan fitrahnya. ${ }^{42}$

Dalam membangun paradigma Islam inklusif peserta didik dipandang sebagai individu yaang memiliki potensi untuk berpikir kritis dan memiliki kepedulian sosial. Bebas berpendapat dan bereksplorasi untuk menemukan pengetahuan dengan bahasanya sendiri tanpa ada paksaan. Dengan demikian peran peserta didik sangat dihormati dalam konteks dia manusia yang mempunyai potensi dan kecerdasan bawaan. Merdeka dan bebas adalah fitrah yang telah dibawa manusia sejak kehadirannya di dunia dan oleh karenanya pendidikan harus sejalan dengan hakikat ini, karena manusia adalah penguasa atas dirinya sendiri. Pendidikan haruslah berorientasi kepada pengenalan realitas yang objektif maupun subjektif karena kesadaran objektif dan subjektif adalah fungsi dialektis dalam diri manusia sehubungan dengan kenyataan yang selalu bertentangan yang harus dipahami dan dihadapi. Maka pendidikan harus dikembalikan pada fungsinya. Pendidikan bukan alat kekuasaan.

Pendidikan tidak dapat berjalan dengan baik tanpa adanya kurikulum. Kurikulum dalam pendidikan Islam yang inklusif dapat terlihat dalam dua aspek yaitu:

\section{1) Aspek Materi}

Dalam pendidikan Islam baik formal maupun nonformal meteri yang disajikan adalah materi yang diuraikan dalam al-Quran. Oleh karena itu materi pendidikan Islam

${ }^{42}$ H.M Arifin, Filsafat Pendidikan Islam, (Jakarta: Bina Aksara, 1987), hlm. 131. 
yang bersumber dari al-Quran harus dipahami, dihayati, diyakini dan diamalkan dalam kehidupan umat Islam.

Adapun gagasan membangun paradigma Islam inklusif kaitannya dengan pendidikan adalah adanya bahasan khusus yang terkait dengan hak minoritas khususnya minoritas dalam kehidupan sosial beragama. Hal ini penting karena Indonesia adalah negara majemuk yang terdiri dari berbagai etnis, budaya, dan agama yang berbeda. Kesadaran menghormati minoritas merupakan keharusan untuk menciptakan kondisi yang aman dan damai sesuai ajaran agama.

Materi lain adalah kebebasan berpikir. Pendidikan Agama Islam yang sesuai dengan gagasan membangun paradigma Islam inklusif mengembangkan kebebasan berpikir supaya banyak ide-ide baru yang muncul, bagi Islam inklusif, pengetahuan, ide, dan gagasan baru akan diperoleh jika adanya kebebasan berpikir. Dalam konteks ini diharapkan akan melahirkan siswa yang kritis, merdeka dan menghargai pluralitas. Pendidikan Islam harus membuka diri atas fenomena global yang saat ini berkembang.

\section{2) Aspek Evaluasi}

Rangkaian terakhir dari proses pendidikan adalah evaluasi, tak terkecuali pada proses pendidikan Islam. Berhasil atau tidaknya pendidikan Islam dalam mencapai tujuannya dapat dilihat setelah dilakukan evaluasi terhadap output yang dihasilkan. Jika hasilnya sesuai dengan apa yang telah digariskan dalam tujuan pendidikan Islam, maka usaha pendidikan itu dapat dinilai berhasil, tetapi jika sebaliknya dinilai gagal. Dari sisi ini dapat dipahami betapa urgennya evaluasi dalam proses pendidikan Islam. ${ }^{43}$

\footnotetext{
${ }^{43}$ Samsul Nizar, Filsafat Pendidikan Islam, (Jakarta: Ciputat Press, 2002),
} hlm. 76 . 
Sesuai dengan paradigma Islam inklusif siswa mempunyai hak untuk membahasakan pengetahuan dengan bahasanya sendiri, kritis dan terbuka terhadap berbagai perbedaan. Siswa adalah pribadi yang kreatif dan mempunyai ide-ide baru untuk mengembangkan kritik pengetahuan terhadap pengetahuan yang konvensional yang otoritatif dan doktriner. Oleh karena itu evaluasi dilakukan tidak hanya pada siswa tetapi juga pada guru dan seluruh stakeholder sekolah agar tidak ada dominasi. Sebab pendidikan merupakan seluruh satuan yang saling bekerjasama, mengevaluasi, membangun untuk bekerjasama.

Di samping materi yang bersifat dialogis dan multi perspektif dengan menggunakan metode yang bervariasi, maka pembelajaran agama perlu dilengkapi dengan kegiatan-kegiatan ko dan ekstra kurikuler yang menopang sikap keterbukaan dan kesediaan untuk bekerjasama dan berkompetisi secara sehat dalam keberbedaan. Di antara beberapa metode dan kegiatan yang bisa diprogramkan untuk itu adalah:

\section{3) Metode Dialogis}

Program dialog antar agama, misalnya: dialog tentang "puasa" yang bisa menghadirkan ulama, pendeta, bikhsu, atau bahkan pemuka aliran kebatinan tertentu. Program ini menjadi sangat strategis, khususnya untuk memberikan pemahaman kepada peserta didik (mahasiswa) bahwa puasa adalah suatu mekanisme universal yang dilakukan oleh manusia untuk membersihkan diri dalam upaya mencapai pencerahan ruhani. ${ }^{44}$ Dengan dialog seperti ini, peserta didik akan menemukan bahwa secara substantif semua keyakinan agama berujung pada suatu nilai universal yang sama. Bahwa kesamaan inilah yang harus terus dibina dengan mempersempit setiap celah perbedaan, biarlah

${ }^{44}$ Nurcholish Madjid, Fiqh Lintas Agama, Jakarta: Yayasan Wakaf Paramadina, 2005), hlm. 224-225 
perbedaan itu menjadi urusan pribadi atau kelompok masing-masing dengan Tuhan mereka.

\section{4) Metode Inovasi}

Program road show lintas agama. Program road show lintas agama ini adalah program nyata untuk menanamkan kepedulian dan solidaritas terhadap komunitas agama lain. Hal ini dengan cara mengirimkan peserta didik (mahasiswa) untuk ikut kerja bakti membersihkan tempat ibadah agama lain..$^{45}$ Melalui kegiatan ini diharapkan peserta didik semakin dapat merasakan kuasa dan keagungan Tuhan, karena ternyata Ia disembah dan dipuja di berbagai tempat dengan berbagai cara.

\section{5) Metode pembelajaran langsung (metode keteladaan)}

Pembelajaran langsung menekankan belajar sebagai perubahan tingkah laku melalui peniruan. Spiritual Work Camp (SWC), dimana peserta didik dari latar belakang agama yang berbeda disatukan dalam perkemahan. Mereka dibagi dalam kelompok-kelompok yang masingmasing terdiri beberapa pemeluk agama yang berbedabeda. Melalui kegiatan ini diharapkan mahasiswa dapat bekerjasama sambil saling bertukar pengalaman ruhaninya masing-masing.

\section{6) Metode pembelajaran kooperatif}

Kerja sosial bersama, yaitu kegiatan pengabdian kepada masysrakat yang dilakukan oleh peserta didik yang berasal dari berbagai latar belakang agama. Melalui kegiatan ini mereka dilatih untuk membuat plat form bersama demi kebaikan masyarakat, bangsa dan negara tanpa memperhatikan masalah etnis, suku, atau agama.

Dari uraian di atas, maka membangun paradigma pendidikan agama Islam berbasis Inklusif dalam kehidupan

${ }^{45}$ Syamsul Ma'arif, Islam dan Pendidikan Pluralisme, makalah disampaikan pada annual Conference Kajian Islam di Lembang 26-30 Nopember 2006, hlm.17. 
sosial beragama multikultur tercermin dalam penetapan tujuan dan kurikulum PAI yang mengarah pada pencapaian kompetensi komunikasi antar umat yang berbeda pemahaman dan ekspresi keagamaannya secara produktif dan konstruktif, untuk mencapai kompetensi itu, maka materi-materi dan kurikulum di lembaga pendidikan perlu disusun dengan mengajukan berbagai perspektif secara dialogis sehingga peserta didik dapat secara bijak memahami berbagai fenomena sosial, budaya, dan keagamaan yang ada disekitarnya.

\section{Simpulan}

Dalam penerapan di Indonesia Konsep Islam inklusif yang pada dasarnya menampilkan kepedulian yang besar terhadap unsur-unsur utama dari kemanusiaan seperti keadilan, HAM, kesetaraan gender, pluralisme, demokrasi serta nilai-nilai kemanusiaan mencakup lima hak dasar manusia Al khuliyat al khomsah menjadi tereduksi oleh kepentingan pragmatis kelompokkelompok tertentu.

Membangun paradigma PAI berbasis inklusif dalam kehidupan sosial beragama multikultur ini merupakan kondisi yang harus diperjuangkan supaya tercipta penghornatan terhadap hal-hak dasar manusia. Hal tersebut menjadi epistimologi serta term penting yang menyentuh wacana keagamaan, sosial maupun politik berdasarkan pada sumber-sumber ajaran Islam yang utama yaitu pada tataran nilai keadilan, persamaan dan demokrasi. Nilainilai tersebut merupakan cerminan pemikiran dan sikap dari membangun paradigma pendidikan agama Islam berbasis inklusif dalam kehidupan sosial beragama multikultur.

Bertolak dari uraian di atas, maka pendidikan Islam berbasis inklusif adalah sebuah alternatif bagi problem masyarakat Indonseia yang majemuk. Melalui membangun paradigma PAI berbasis inklusif dalam kehidupan sosial beragama multikultur ini, maka lulusan lembaga pendidikan dan sarjana-sarjana alumni 
Pendidikan Islam Berbasis Inklusifisme dalam Kehidupan Multikultur

perguruan tinggi diharapkan mampu bersaing dan bersanding secara positif dan konstruktif demi pengembangan diri mereka. 


\section{DAFTAR PUSTAKA}

Arifin M. H, Filsafat Pendidikan Islam, Jakarta: Bina Aksara, 1987. Anwar, M. Syafi'i, "Kata Pengantar" dalam Abdurrahman Wahid, Islamku, Islam Anda, Islam Kita: Agama Masyarakat Negara Demokrasi, Jakarta: The Wahid Institute, 2006.

Dhakiri, M. Hanif, 41 Warisan Kebesaran Gus Dur, Yogyakarta: LkiS, 2010.

Djauhary Zaidan, Pedoman Dasar Kerukunan Hidup Beragama, Jakarta: Proyek Pembinaan Kerukunan Hidup Beragama, 1984.

Departemen Agama RI, Al-Qur'an dan Terjemah, Bandung: CV. Penerbit J-Art, 2005.

Engineer Ali Asghar, Hak-hak Perempuan dalam Islam, terj. Farid Wajidi dan Cici Farkha Assegaf, Yogyakarta: Lembaga study Pengembangan Perempuan dan Anak, 1994.

Huda Nurul, Multikulturalisme Dalam Bayang-bayang Histografi

Resmi Nasional dalam Sururin (ed) Nilai-Nilai Pluralisme Dalam Islam, Bandung: Nuansa, 2005.

Madjid Nurcholish, Fiqh Lintas Agama, Jakarta: Yayasan Wakaf Paramadina, 2005.

Ma'arif Syamsul, "Islam dan Pendidikan Pluralisme", makalah dipresentasikan pada Annual Conference Kajian Islam di Lembang 26-30 Nopember 2006.

Machasin, "The Concept of Human Being", h. 10 dan 12; dalam

'Ali Khalil Abu al-'Ainain, Falsafah al-Tarbiyah al-Islamiyyah fi al-Qur'an al-Karim, pengantar: 'Abd al-Gani 'Abbud, t.tp.: Dar al-Fikr al-'Arabi, 1980.

Madjidi Busyairi, Konsep Kependidikan Para Filosof Muslim, Yoyakarta: Al Amin Press, 1997. 
Nizar Samsul, Filsafat Pendidikan Islam, Jakarta: Ciputat Press, 2002.

Rubaidi, Radikalisme Islam, Nabdlatul Ulama, Yogyakarta, Logung Pustidaka, 2010.

Sahrur, Al Qur'an wa Al Kitab, Beirut: Syarikah al Mathbu'at, 2000.

Shaleh Rachman Abdul, Pendidikan Agama dan Pendidikan Keagamaan : Visi,Misi dan Aksi, Jakarta: PT. Gemawindu Pancaperkasa, 2000.

Tim Penyusun Kamus Pusat Pembinaan dan Pengembangan Bahasa Departemen Pendidikan dan Kebudayaan, Kamus Besar Bahasa Indonesia, Jakarta: Balai Pustaka, 1989.

Yusri, FM. Mumammad, "Prinsip Pendidikan Multikulturalisme Dalam Ajaran Agama-agama Di Indonesia", Jurnal Kependidikan Islam, Jurusan Kependidikan Islam Fakultas Tarbiyah UIN Sunan Kalijaga, Vol. 1, No 2 Juli-Desember, 2008.

Wahid Abdurrahman, Islamku Islam Anda Islam Kita, Jakarta: Wahid Institute, 2006., Pribumisasi Islam, dalam Muntaha Azhari dan Abdul Munim Saleh (ed), Islam Indonesia Menatap Masa Depan, Jakarta : P3M, 1989., "Pluralisme Agama Dan Masa Depan Indonesia" makalah pada Seminar Agama dan Masyarakat, Universitas Kristen Satya Wacana, Salatiga, 20 November 1992.

Dialog Agama dan Masalah Pendangkalan Agama" dalam komaruddin Hidayat dan Ahmad Gaus AF (ed), Passing Over melintasi Batas Agama, Jakarta: Gramedia Pustaka Utama, 1998. , Membangun Demokerasi, Bandung: PT. Rosdakarya, 1999. - Mengurai Hubungan Agama dan Negara, Jakarta: PT Gramedia Widiasarana Indonesia, 1999., "Hubungan Antar Agama Dimensi Internal-Eksternal" dalam Sudiarjo (ed), Dialog Intra Religius, Yogyakarta: Kanisius, 
1994., Mengurai Hubungan Agama dan Negara, Jakarta: PT Gramedia Widiasarana Indonesia, 1999., "Beberapa Aspek Teoritis dari Pemikiran Politik dan Negara Islam" dalam Imron Hamzah dan Choirul Anam (Ed), Abdurrahman Wahid Diadili Kiai-kiai: Sebuah Dialog Mencari Kejelasan, Surabaya : Jawa Pos, 1989.

, Muslim di Tengah Pergumulan, Jakarta: Lappenas, 1981. , Partai Kebangkitan Bangsa, Jakarta: PKB Pres, 2005.

Wilson, T. H. Sex and Gender: Making cultural sense of Civilization, New York: E. J. Brill, 1989. 